\title{
ArcheoSciences
}

Revue d'archéométrie

\section{'More like the work of fairies than of human beings': the filigree on the 'Tara' brooch, a masterpiece of late Celtic metalwork}

"Cuvre des fées plus qu'ouvre des hommes ": le filigrane de la fibule de

"Tara", un chef d'oeuvre de l'orfêvrerie celtique tardive

\section{Niamh Whitfield}

\section{OpenEdition}

\section{Journals}

\section{Electronic version}

URL: https://journals.openedition.org/archeosciences/2257

DOI: 10.4000/archeosciences.2257

ISBN: 978-2-7535-1598-7

ISSN: $2104-3728$

Publisher

Presses universitaires de Rennes

\section{Printed version}

Date of publication: 31 December 2009

Number of pages: $235-241$

ISBN: 978-2-7535-1181-1

ISSN: $1960-1360$

Electronic reference

Niamh Whitfield, "'More like the work of fairies than of human beings': the filigree on the 'Tara' brooch, a masterpiece of late Celtic metalwork", ArcheoSciences [Online], 33 | 2009, Online since 10 December 2012, connection on 01 February 2022. URL: http://journals.openedition.org/archeosciences/2257 DOI: https://doi.org/10.4000/archeosciences.2257 


\title{
'More like the work of fairies than of human beings': the filigree on the 'Tara' brooch, a masterpiece of late Celtic metalwork
}

\author{
"Cuvre des fées plus qu'ouvre des hommes": \\ le filigrane de la fibule de "Tara", un chef d'oeuvre de l'orfevrerie celtique tardive
}

\author{
Niamh Whitfield*
}

\begin{abstract}
In the early Middle Ages, Irish goldsmiths achieved a rare mastery of gold working techniques. The 'Tara' brooch, dated to c. 700 $\mathrm{AD}$, shows many characteristics of this late Celtic style of metalwork. This paper discusses the manufacture of its filigree, drawing on the writer's microscopic study and hitherto unpublished scientific investigations carried out in the British Museum in 1962-1963.
\end{abstract}

Résumé : Au Haut Moyen Âge les orfevres irlandais ont réussi un niveau technique rare dans les arts du métal. La fibule de 'Tara', fabriquée vers 700 de notre ère, présente un grand nombre de traits distinctifs de ce style celtique tardif. Cet article décrit la fabrication des filigranes de cette fibule. L'étude est basée sur des examens au microscope optique par l'auteur, et aussi sur des études scientifiques inédites faites au British Museum en $1962-1963$.

Keywords: Beaded wire, Celtic, filigree, granules, Ireland, 'jewellers' stitches'.

Mots-clés : Fil perlé, Celtique, filigrane, granules, Irlande, millegriffes.

\section{INTRODUCTION}

Although the art of goldsmithing, including the manufacture of gold filigree, flourished in prehistoric Ireland, the working of gold seems to have been completely forgotten there in the early centuries of our era. However, in the $6^{\text {th }}$ and $7^{\text {th }}$ centuries $\mathrm{AD}$, the Irish, through their missionary activities, forged strong contacts with rich and powerful Anglo-Saxon, Frankish and Lombardic leaders. One result of these contacts was the reintroduction of gold and simultaneously, it seems, of gold filigree. The influence of Germanic,

*47 Faroe Road, London W14 OEL, UK. (mail@niamhwhitfield.com) and in particular Anglo-Saxon, traditions is clearly seen in the new so-called 'Hiberno-Saxon' (or 'late Celtic') filigree style they developed (Whitfield, 1987; 2007). However, the Irish goldsmiths also introduced innovations, and developed the craft to an exceptionally high degree of sophistication and virtuosity. The 'Tara' brooch (Fig. 1), which dates to the late $7^{\text {th }}$ or very early $8^{\text {th }}$ century $\mathrm{AD}$, is one of the earliest pieces of Irish metalwork to display this new style of filigree.

The brooch was discovered in 1850 at Bettystown, Co Meath, on the east coast of Ireland, rather than at the nearby, ancient necropolis of Tara. Its first owners, 

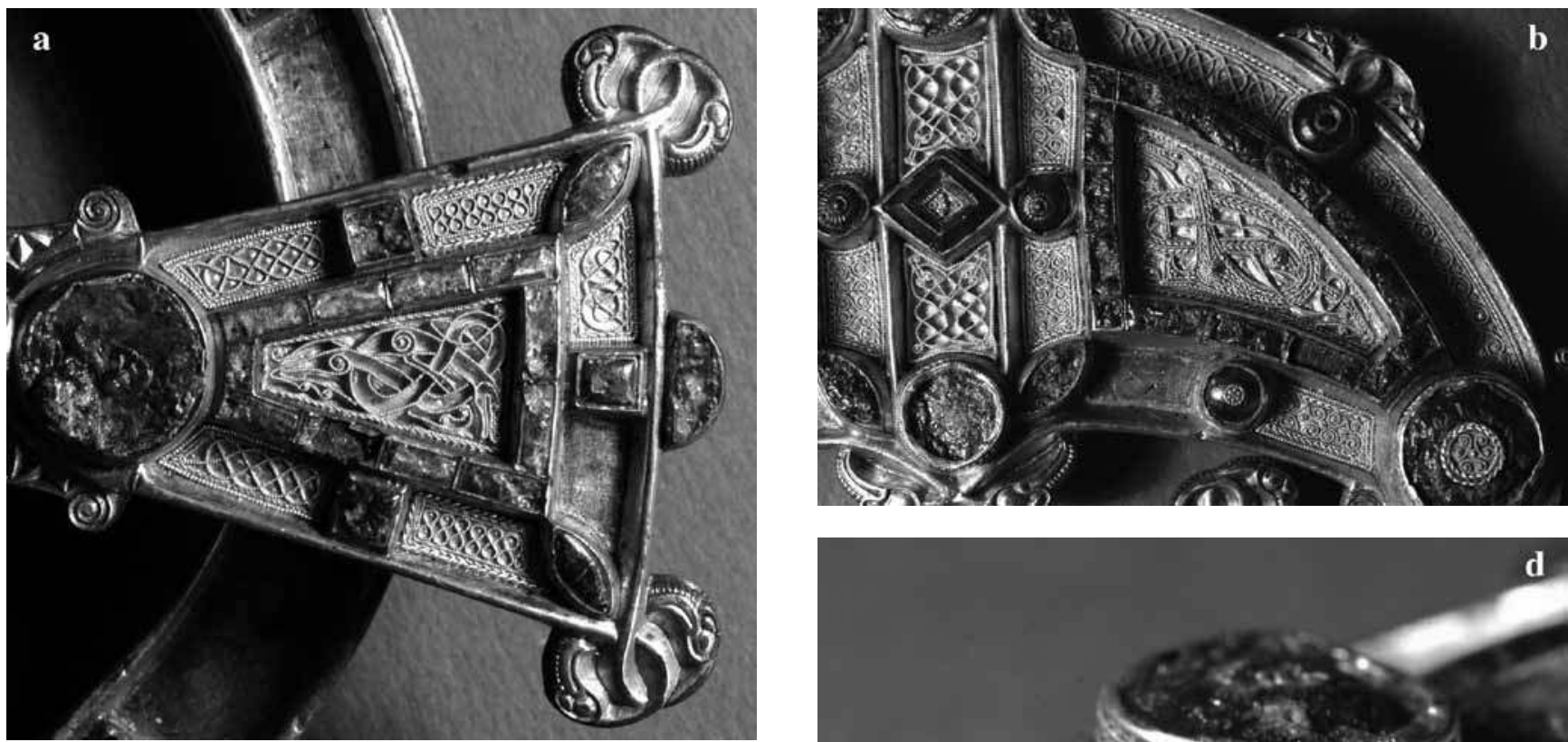

C
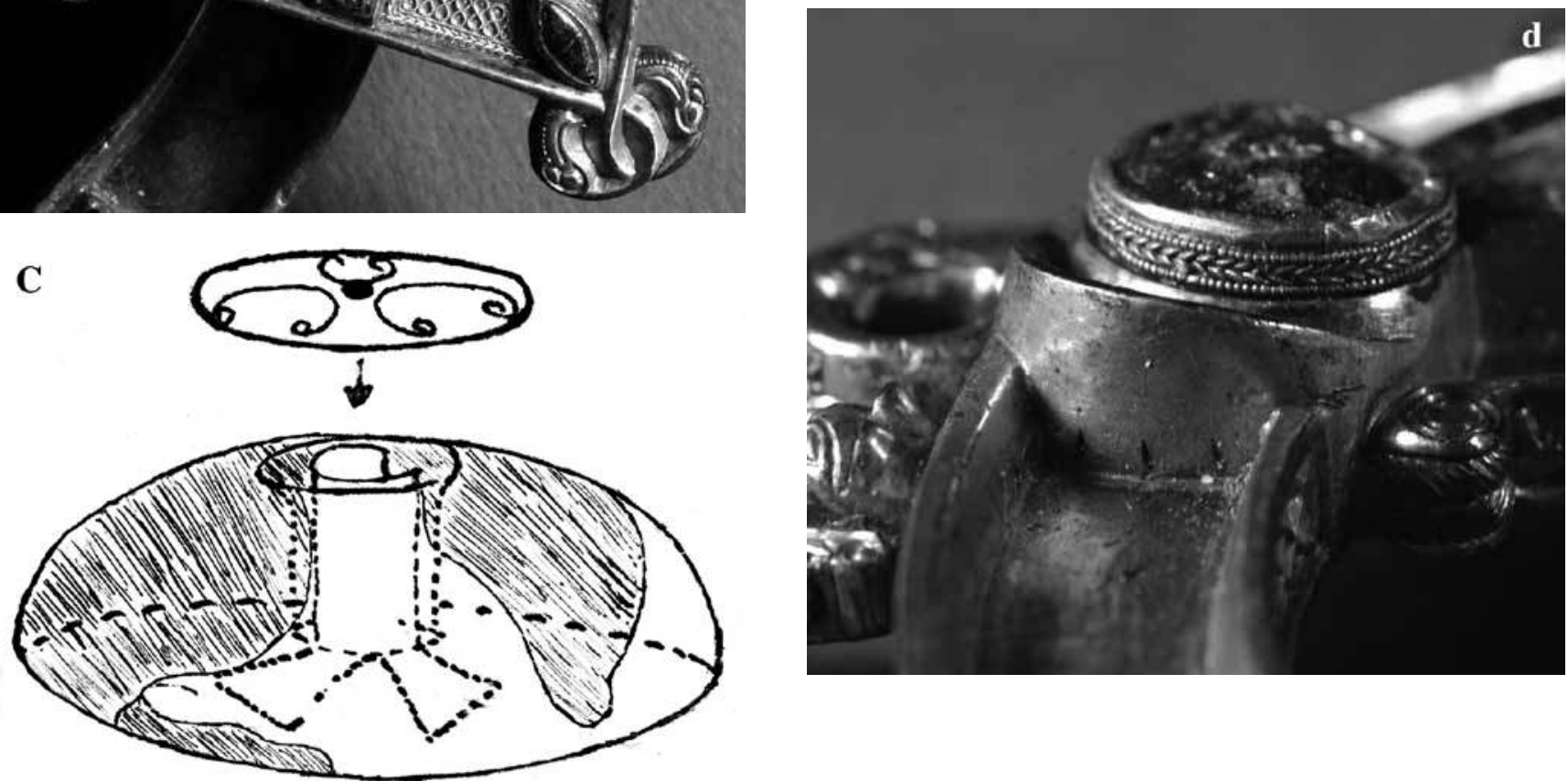

Figure 1: (See colour plate) 'Tara' brooch filigree: a. Pin-head; b. Part of the brooch; c. Diagram showing attachment of filigree disc to amber stud; d. Amber stud on right side. (Photography: a, b, d: reproduced by the kind permission of the National Museum of Ireland; Drawing: M. Bimson). Figure 1: (Voir planche couleur) Filigranes de la fibule de "Tara" : a) Tête de l'ardillon; b) Une partie de la fibule; c) Schéma de la monture du disque orné de filigranes sur une perle d'ambre; d) Perle d'ambre à droite. (Photographies : $a, b$, d: reproduction avec la permission du Musée national d'Irlande; dessin : M. Bimson).

Waterhouse and Co., jewellers of Dame Street, Dublin, were in the habit of attaching evocative names to brooches of which they sold replicas: they are responsible for the misleading reference to Tara in the 'name' given to the brooch. The object was almost completely intact when discovered, but some filigree was subsequently lost. It measures $8.6 \mathrm{~cm}$ in diameter and weighs $224.36 \mathrm{~g}$. Although it is cast in silver, the underlying silver is barely visible, because it is elaborately decorated on all faces with a profusion of designs and materials, either inset into the brooch or directly applied on its surface.
This paper is concerned only with the manufacture of its filigree, all of which is made of gold. The writer, an archaeologist, not a scientist, has not been able to carry out any scientific analyses. This paper draws primarily on her microscopic examination of the object in the National Museum of Ireland. However, when the 'Tara' brooch was cleaned in the British Museum Laboratory in the early 1960s, it was closely examined using the scientific methods then available. Robert Organ has kindly made available an unpublished lecture in which he presented the new discoveries made at that time (Organ, 1964), and access has also been given to other files 
in the British Museum. In addition, some excellent black and white photographs of the 'Tara' brooch taken in the British Museum in the 1960s, not hitherto published in the specialist literature, are reproduced here.

With the exception of some flattened gold beaded wire as rings around the three rivets on the back, gold filigree is found only on the front of the 'Tara' brooch. There, it was never applied directly. Instead, it was soldered to small backplates made of thin gold sheet to form individual panels, each edged by a filigree border and decorated with an allover pattern 'drawn' with wires and granules (Figs. 1 and 2). The thickness of the gold sheet was not measured, but a back-plate measured on the similar Hunterston brooch, from the west coast of Scotland, was found to be $0.1 \mathrm{~mm}$ thick (Stevenson, 1974: 23), while another, on the closely related Westness brooch, from a $9^{\text {th }}$-century Viking grave in Orkney, was 0.1-0.15 mm thick (Stevenson, 1989: 248). Nor were analyses of the solder joining the wires and granules to the back-plates carried out. However, clear traces of metallic solder were observed at some points by both the writer and by the British Museum team.

\section{Mounting THE FiLigree PanelS}

Filigree panels were fixed on the front of the brooch:

- In sunken compartments about $3 \mathrm{~mm}$ deep, covering the front of the brooch and pin-head - twenty-eight compartments in all, separated from each other by studs of various types.

- On the tops and edges of the five dome-shaped amber studs.

- On the tops of three of the glass studs, one lozengeshaped and two circular.

Different methods were used to attach the gold panels in each of the three different locations, and these will now be described.

\section{In the sunken compartments}

After the brooch had been cast, the walls of the sunken compartments were gilded, and wires and granules made separately and soldered to small gold back-plates, which had been cut exactly to shape. These were then fitted snugly in the base of each compartment (Fig. 1a, b). How were they held in place there?

When the brooch arrived in the British Museum for conservation in the 1960s, it was discovered that the gold panels were secured by three types of mastic: red wax, beeswax, and (apparently, the earliest of the three) a mixture

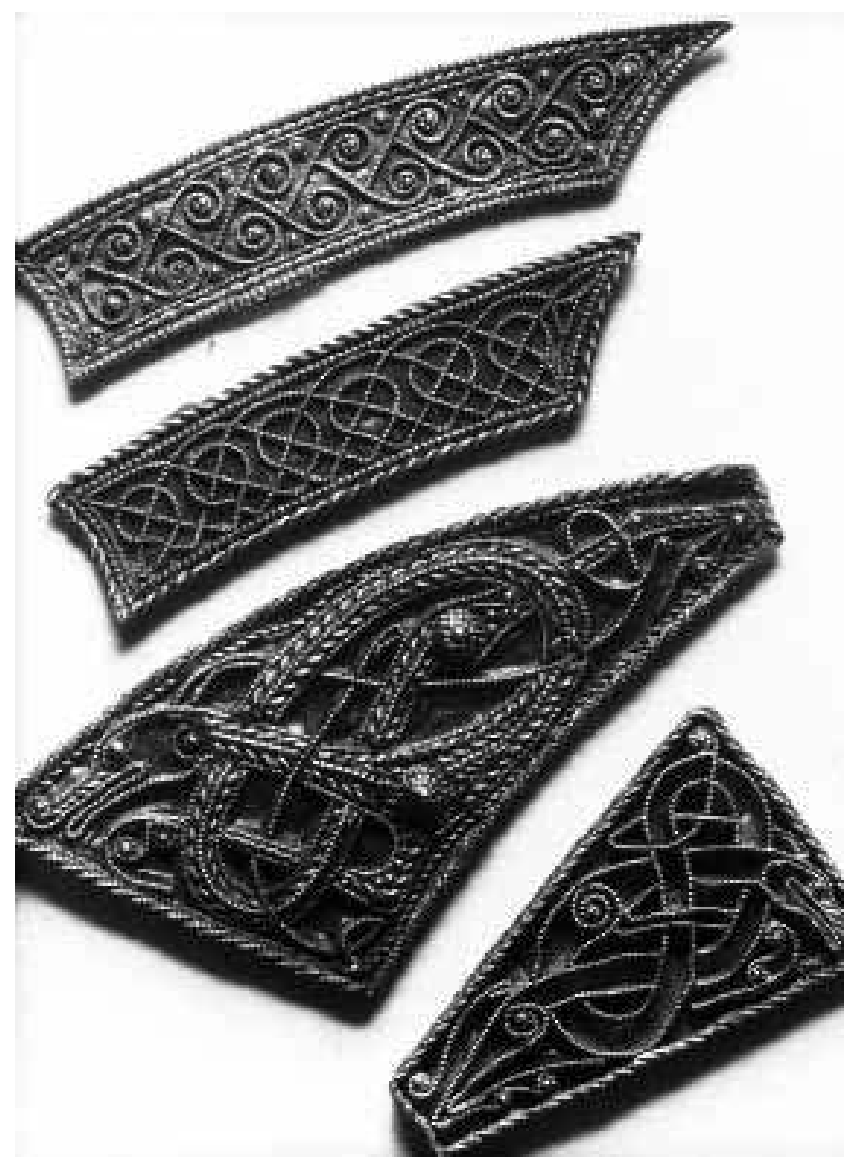

Figure 2: 'Tara' brooch: four filigree panels removed from their compartments (Photography: British Museum Conservation Laboratory).

Figure 2 : Fibule de "Tara " Quatre plaques de filigranes enlevées de leur boites. (Photographie : Laboratoire de Conservation du British Museum).

of rosin and beeswax (Organ, 1964). However, the mastic was so thick that the panels were raised above the level of features in the cell walls, which seems to have been the primary method of holding them in place.

These were 'jewellers' stitches', i.e., tiny tongues of silver, gouged from the compartment wall, which projected over the edge of each back-plate and held it in place (Fig. 3). Some intact stitches survive on the 'Tara' brooch, but many have corroded and broken off, which partly explains the loss of the minute panels in the $19^{\text {th }}$ century. Traces of this are still visible, because they pierced the gilding on the compartment walls revealing the silver beneath (Fig. 1d). The stitches were at a height from the bottom of the cells that corresponded exactly with the thickness of the filigree panels (Werner, unpublished). It was therefore concluded that originally jewellers' stitches alone secured the filigree panels, and that the mastic was modern, applied to pre- 


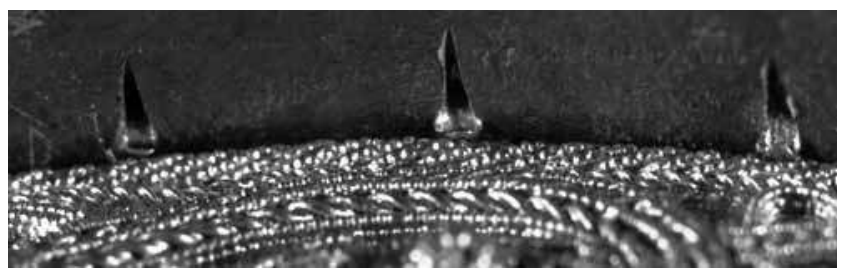

Figure 3: 'Tara' brooch: three 'jewellers' stitches' (Photography: British Museum Conservation Laboratory).

Figure 3 : Fibule de "Tara" : trois "millegriffes». (Photographie : Laboratoire de Conservation du British Museum).

vent further losses; the remaining panels are now secured by Durafix (Organ 1964).

Jewellers' stitches (also known as 'bead settings' or 'milligraining') are used in modern stone setting (Untracht, 1982: 619-621), but in the early Middle Ages they seem to occur only in a late Celtic context.

\section{On the dome-shaped amber studs}

Filigree originally decorated each of the five dome-shaped amber studs, in two positions: (i) on flat discs, about $3.25 \mathrm{~mm}$ in diameter, fixed to the apex of the studs, only two of which survive today (Fig. 1b), and (ii) as a filigree collar circling the base of the studs, the largest of which is approximately $7 \mathrm{~mm}$ in diameter (Fig. 1d). Scrutiny in the British Museum revealed that these were secured in the following ways:

(i) In the case of the filigree on the tops of the amber studs, the latter were drilled through their centres, and each gold disc soldered to a hollow gold tube to make a mushroom-like unit. This was then passed through the drilled hole, and the tube splayed out at the lower end, anchoring the filigree-decorated disc to the top of each stud (Fig. 1c). The gold tube can still be seen, embedded in a stud that has lost its filigree disc (Fig. 1d). Moreover, when another stud was removed from its socket, scrutiny of the back revealed that only just over half the tube is intact; the rest was carefully cut away by the goldsmith, who must have had to use gold sparingly (Organ, 1964).

(ii) In the case of the filigree collars, the circumference of the stud was enclosed in a ring of thin gold sheet: a decorative band of filigree wire is soldered around it (Fig. 1d). When the studs were removed from their sockets, the gold sheet could be seen to extend underneath each one, where it had been nicked and bent back under the stud to hold the sheet as a whole fast.

The amber studs in their entirety appear to have been secured to the brooch itself by a rivet passing through a hole in the floor of each stud socket.

\section{On the three glass studs}

A third method was used to attach the little filigree panels to the tops of the glass studs (Fig. 1b). Mavis Bimson of the British Museum observed that on the lozenge-shaped stud (maximum width: $12 \mathrm{~mm}$ ), the glass slightly overlaps the filigree panel, particularly on the upper part of the lozenge. This showed that the glass must have flowed into this position. Thus, the gold lozenge-shaped filigree panel was placed on the stud when the glass was molten, and stuck to it when it solidified. This seems to have been the most secure method of all of attaching the filigree panels to the 'Tara' brooch, because only on the tops of the glass studs has all the original filigree survived.

\section{Ornamental Wires aNd gRanUles}

As Figures 4 and 5 show, many ornamental forms of filigree adorn the 'Tara' brooch. Individual plain round wires of gold are not used decoratively. However, as indicated below, individual strands are twisted together to form wire ropes. These strands are solid and helical marks occasionally appear, suggesting that the round wire was made by block-twisting, i.e. by twisting a gold strip of squarish or rectangular section and then rolling it between two flat surfaces to produce a smooth round-sectioned wire (Whitfield, 1990: 14).

The following simple filigree forms are found:

(a) Beaded wire (Fig. 4a): All the beading is located at right-angles to the long axis of the strand. Although there are some flaws, the beads normally follow each other in an orderly succession and gaps between them are rare. They are generally regular in form, and a medial seam (äquatorschnitt) is often present. All wires appear to have been hand-rolled at right-angles under a rolling swage or 'beading file'. This tool probably had a single groove flanked by teeth, like the tool described by Theophilus (Whitfield, 1998: 62), but the possibility of more grooves cannot be ruled out. A number of beaded wires were measured across their broadest point. Three, and possibly four, gauges seem to have been made deliberately. In descending order, they have maximum diameters of approximately $0.35 \mathrm{~mm}, 0.25 \mathrm{~mm}, 0.2 \mathrm{~mm}$, and $0.15 \mathrm{~mm}$.

A few measurements were made of the number of beads per five divisions on the graticule, which equalled c. 0.9 $\mathrm{mm}$. On the beaded wire measuring c. $0.25 \mathrm{~mm}$ in diameter there were approximately four beads per $0.9 \mathrm{~mm}$, while on the beaded wire of c. $0.15 \mathrm{~mm}$ in diameter there were approximately six beads per $0.9 \mathrm{~mm}$. This suggests that a finer tool was used to bead the latter. 


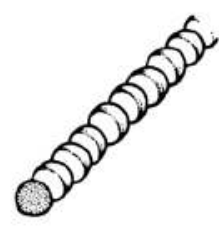

a

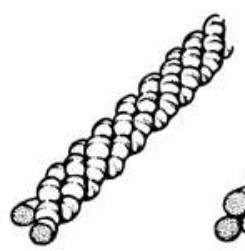

e

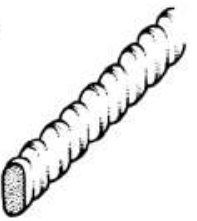

b

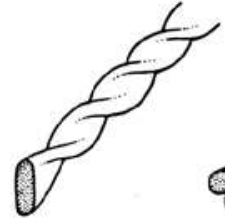

C

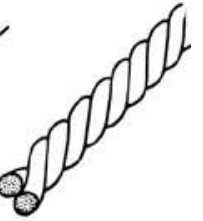

d

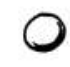

h

Figure 4: 'Tara' brooch: simple filigree forms (Drawing: Nick Griffiths).

Figure 4 : Fibule de "Tara" : Formes simples de filigrane. (Dessin: Nick Griffiths).

(b) Flattened beaded wire on edge: The scalloped ribbon illustrated in Figure 4b is, in fact, beaded wire which was hammered flat, and set on the edge in the manner described by Theophilus (Whitfield, 1998: 79). This is evident because, when these wires are examined under the microscope, it is visible that the undulations on each side not only match, but are also often linked by tiny transverse lines representing the breaks between each bead. This produces a very narrow upper surface, in this case of the order of 0.1 $0.15 \mathrm{~mm}$ wide.

(c) Twisted ribbon (Fig. 4c): This consists of a flat strip of gold that has been twisted by securing at one end and turning the other. The torsion is often uneven. The ribbons themselves were not measured, but they are all similarly narrow. Where measured, the thickness of the ribbon was found to be just under $0.1 \mathrm{~mm}$, and the width of the twisted strand as a whole c. $2.5 \mathrm{~mm}$.

(d) 2-ply twisted wire rope (Fig. 4d) (sometimes known as 'rope-twist' or 'twined wires'), made by twisting two round wires together, either to the right or to the left. The torsion is fairly even. On some panels the individual round wires were found to be c. $0.17-0.2 \mathrm{~mm}$ in diameter; on others c. $0.12 \mathrm{~mm}$.

(e) 2-ply twisted beaded wire rope (Fig. 4e), made by twisting two beaded wires together in the manner described above. These wires were not measured, but the finest beaded wires seem to have been used, probably with a diameter of the order of $0.15 \mathrm{~mm}$.

(f) 3-ply twisted wire ropes (Fig. 4f), a variation of (d) made by twisting three, rather than two, plain round wires to produce a thicker cord. No measurements were recorded.

(g) 3-ply twisted beaded wire rope (Fig. 4g), a variant of (e) made by twisting three, rather than two, beaded wires together. The individual beaded wires appear to be of very fine gauge, but were not measured.

(h) Granules (Fig. 4h), i.e. minute spheres formed when small chips of gold are melted, and upon cooling coalesce naturally into minuscule spheres which retain their shape. Some variations in granule size can be seen with the naked eye. Diameters of c. $0.15,0.25,0.35$ and $0.45 \mathrm{~mm}$ were The following forms occur.

Not only are there a large number of simple filigree forms on the 'Tara' brooch, but a range of stock combinations of various types also occur, as Figure 5 shows. Sometimes wires and/or a granule are juxtaposed; alternatively, one wire is placed on top of another; at other times yet, wires are coiled. as follows:

The imitation plait (Fig. 5a) (sometimes also known as a 'herring-bone'), formed by neatly paired 2-ply wire ropes, one twisted to the right, the other to the left, so as to form a succession of ' $V$ ' patterns along its length and create the illusion of plaiting. The illusion depends on extraordinary precision, particularly as the individual round wires which form the components of the 'ropes' may measure only $\mathrm{c}$. $0.15 \mathrm{~mm}$ in diameter.

The 3-strand band has a thicker central and finer flanking strands of beaded wire, in this case measuring c. 0.25 and $0.15 \mathrm{~mm}$ in diameter, respectively. Figure $6 \mathrm{~b}$ shows a similar arrangement but with a finer central wire. The individual

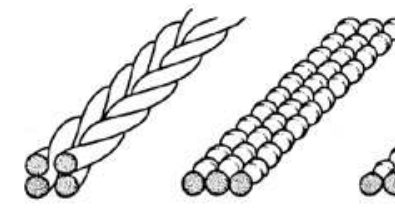

a

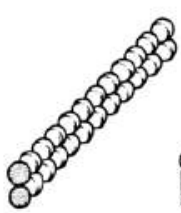

e

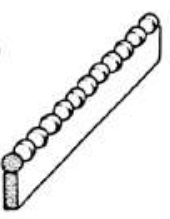

f

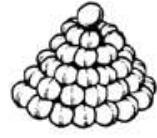

g

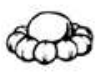

h
Figure 5: 'Tara' brooch: combined filigree forms (Drawing: Nick Griffiths).

Figure 5 : Fibule de "Tara : Formes combinées de filigrane. (Dessin: Nick Griffiths).

ArcheoSciences, revue d'archéométrie, 33, 2009, p. 235-241 
wires are sometimes of different lengths and were not cut as a band. They may have been soldered separately to the back-plate.

The herring-bone band (Fig. 5c), which builds on the imitation plait by adding a beaded wire to either edge.

The herring-bone band with spine (Fig. 5d), a variant on the above formed by placing a wire between the individual wire ropes in the middle of the band.

One beaded wire on top of another (Fig. 5e). It seems that the two wires were soldered together before being mounted on the back-plate, because they appear to have been cut in one piece. The two wires appear to be of about the same gauge; the upper one is c. $0.25 \mathrm{~mm}$ in diameter.

$A$ beaded wire on a ribbon on edge (Fig. 5f), a variant on the theme described above at (e): the uppermost beaded wire is soldered onto a flat ribbon of gold set on edge, the two components being again probably soldered together before being mounted on the back-plate. The beaded wire has a diameter of the order of $0.15-0.2 \mathrm{~mm}$. The height of the ribbon was not measured, but it is relatively broad from edge to edge, so that this particular combination creates an effect comparable to empty cloisonné cells. However, study in the British Museum established that the 'cells' between the wires were not infilled.

A conical spiral (Fig. 5g) formed of a beehive-shaped cone of beaded wire capped by a granule. It is difficult to see how many wires are involved, but similar cones on the Ardagh chalice were made by coiling up a pair of beaded wires (Organ, 1973: 258, pl. 41).

A collared granule (Fig. 5h), which consists of a single granule enclosed in a ring of beaded wire, to form a dot and ring.

None of the individual forms and combinations listed above is unique to the 'Tara' brooch: all are part of the stockin-trade of the late Celtic goldsmiths. Three compound forms (one beaded wire on top of another; a beaded wire on a ribbon on edge; and the conical spiral) seem to be Celtic innovations, but all the other forms have longer pedigrees, some originating in the Classical world (Whitfield, 1987; 2007).

Nevertheless, the 'Tara' brooch filigree has a very distinctive character. As shown above, it is remarkable for the sheer number and diversity of its components, and for the extreme delicacy of the wire. Not only is the wire extremely fine, but also the panels themselves are very small. This aspect can be illustrated by making reference to Figure 2, which shows four panels photographed together. The two long narrow panels at the top are just $4 \mathrm{~mm}$ wide. The panel beneath, which is the largest on the brooch, has a maximum width of $12 \mathrm{~mm}$, and a chord of $20 \mathrm{~mm}$ along its curved side. The lowest panel is $14 \mathrm{~mm}$ high and has a maximum width of 8 $\mathrm{mm}$. Yet, these minute panels are ornamented with a wide range of types of filigree.

There is order among all these features. The front of the 'Tara' brooch is sub-divided into different zones of ornament (Fig. 1), and, technically, whatever the type of pattern displayed, the panels in each zone are treated as a unit. However, within these constraints, the goldsmith managed to avoid repeating himself to an extraordinary degree, and to create many variations on simple themes.

Beaded wire is always used to 'draw' the motif in the panel centres, but different variants of it appear in the different ornamental zones. To take Figure 2 as an example, the top two panels are from the side-compartments on the brooch (Fig. 1b). The motifs there differ, but each is outlined by a flattened beaded wire on edge, as on all other panels in this zone. Here, the choice of wire imposes order, even if the patterns display diversity. In contrast, the outline of the interlaced animal in the sub-trapezoidal panel below (from the body of the brooch, Fig. 1b) is 'drawn' by one beaded wire on top of another. On the other hand, the other interlaced animal at the bottom of this photograph (which is from the centre of the pin-head, Fig. 1a) is outlined by a beaded wire on a ribbon on edge. Yet another variant is used to 'draw' the interlace on the hoop: a 3-strand band of beaded wire (not illustrated). It is remarkable that nowhere on the 'Tara' brooch is simple beaded wire alone used to draw a pattern.

Simple beaded wire is reserved for panel borders, where it may be juxtaposed with twisted ribbon and twisted wire ropes of various types. These borders show a similar virtuoso spirit. A particular ploy was to juxtapose twisted ribbon with twisted wire ropes, plain or beaded, 2-ply or 3-ply, to form a patterning reminiscent of the more traditional imitation plait'. Given the different nature of the strands, however, the resultant 'plait' is slightly 'off-key', as the juxtaposed twists fail to match up exactly.

The length to which the goldsmith was sometimes prepared to go in order to vary the effect is evident from a comparison between the two panels with animal ornament in Figure 2. On the body of the brooch (Figs. 1b, 2), the border is composed of an outer 3-ply beaded twisted wire rope, inside which is a, far finer, twisted ribbon (Fig. 2). The animal's outline, 'drawn' by one beaded wire on top of another, is infilled with opposed 2-ply twisted plain wire ropes, separated from each other by a beaded wire spine, but where the body expands there are also granules and short strands of twisted ribbon. The shoulder and hip are each emphasised by a beaded wire cone, while other focal points, including the eye, are marked by granules. It is difficult to identify the particular forms of filigree on this panel without 
magnification, but the diverse elements have the effect of creating considerable glitter.

On the panel with an animal ornament on the pin-head (Figs. 1a, 2), on the other hand, the filigree is relatively sparse: there is a single-wire border of twisted beaded wire rope; the animal is outlined by a beaded wire on a ribbon on edge, and there are granules on focal points. Scrutiny of the border, however, reveals a very subtle detail: 2-ply twisted beaded wire rope is used for most of its length. At this point, the smith drew attention to the animal's head by replacing the 2-ply rope with a short length of thicker, 3 -ply beaded rope.

These examples must suffice for showing how ingenious and delicate is the filigree on the 'Tara' brooch. Not only is the work carried out on a minute scale, it is also so exact that it can be greatly magnified without revealing flaws in manufacture. This is no doubt one of the reasons why when the 'Tara' brooch was displayed in London in 1863, one of the Castellani brothers remarked that it had been "worth a journey from Italy to see it" (Waterhouse et al., 1897), and why a contemporary commentator in the London Times remarked that it was "more like the work of fairies than of human beings" (O’Neill, 1863: 54).

\section{Acknowledgements}

I am grateful to Eamonn Kelly and other staff of the National Museum of Ireland for facilitating the examination of the 'Tara' brooch; to Robert Organ for giving me the text of his unpublished lecture; to Susan La Niece for locating photographs in the British Museum, and to Claudio Mari and Ivor Kerslake for digitizing them; and to Barbara Armbruster for other help.

\section{References}

O'NeILL, H., 1863. The fine arts and civilization of ancient Ireland. Dublin, George Herbert.

Organ, R., 1964. Text of a lecture on the 'Tara' brooch given to the UK Group of IIC on 28 May 1964. Department of Conservation and Scientific Research, The British Museum. Unpublished.

Organ, R., 1973. Examination of the Ardagh Chalice - A Case History, in W.J. Young (ed.), Application of Science in Examination of Works of Art. Proceedings of the Seminar: June 15-19, 1970. Boston, Massachusetts, Research Laboratory, Museum of Fine Arts, 238-271.

STEVEnson, R.B.K., 1974. The Hunterston brooch and its significance. Medieval Archaeology 18: 16-42.

STEVEnson, R.B.K., 1989. The Celtic brooch from Westness, Orkney, and hinged pins. Proceedings of the Prehistoric Society of Scotland 119: 469-477.

Untracht, O., 1982. Jewelry concepts and technology. London, Robert Hale.

WATERHOUSE and Co, 1852. Ornamental Irish Antiquities. Irish Antique Brooches. Dublin, Waterhouse \& Co.

Waterhouse and Co, 1897. Letter dated 3 December 1897 to Daily Irish Independent.

WERnER, A., Unpublished. Text of an undated lecture on the 'Tara' brooch and Ardagh chalice. Department of Conservation and Scientific Research, The British Museum.

Whitfield, N., 1987. Motifs and Techniques of Celtic Filigree: Are they Original? in M. Ryan (ed.), Ireland and Insular Art AD 500-1200. Dublin, Royal Irish Academy, 75-84.

Whitfield, N., 1990. Round wire in the early Middle Ages. Jewellery Studies 4: 13-28.

Whitfield, N., 1998. The manufacture of ancient beaded wire: experiments and observations. Jewellery Studies 8: 57-86.

Whitfield, N., 2007. Motifs and Techniques of Early Medieval Celtic filigree: their Ultimate Origins, in R. Moss (ed.), Making and Meaning. Dublin, The Four Courts Press, 18-39. 
